\title{
MEDIA PROMOSI PADA DINAS PARIWISATA DAERAH ISTIMEWA YOGYAKARTA DALAM MENINGKATKAN KUNJUNGAN WISATAWAN
}

\author{
Dinda Puspa Prastiyanti ${ }^{(1)}$, Yulianto ${ }^{(2)}$ \\ (1)(2)Program Studi Perhotelan, Universitas Bina Sarana Informatika \\ dindapuspa7@gmail.com,yulianto.ylt@bsi.ac.id \\ Submitted: 10 September 2019 Revised: 18 September 2019 \\ Accepted: 30 September 2019
}

\begin{abstract}
ABSTRAK
Dinas Pariwisata DIY merupakan unsur pelaksana daerah di bidang kepariwisataan yang memiliki tugas untuk melaksanakan urusan bidang pariwisata, kewenangan dekonsentrasi serta tugas pembantuan yang diberikan oleh pemerintah. Sehubungan dengan kegiatan kepariwisataan Dinas Pariwisata DIY berusaha untuk dapat selalu menyampaikan informasi atau mempromosikan berbagai macam kegiatan pariwisata di Daerah Istimewa Yogyakarta dengan tujuan untuk meningkatkan kunjungan wisatawan ke Daerah Istimewa Yogyakarta. Dinas Pariwisata DIY dalam promosi menghadapi kendala antara lain keterbatasan anggaran, infrastruktur yang belum optimal, kurangnya kualitas Sumber Daya Manusia (SDM), kurangnya sinergitas atau kesamaan orientasi kepentingan dengan Dinas Pariwisata di kabupaten/kota, dan kurangnya kesadaran masyarakat dalam kepariwisataan. Metode pengumpulan data dalam penelitian adalah metode observasi (pengamatan), wawancara, dokumentasi, partisipatif, dan studi pustaka dengan metode analisis berupa analisis deskriptif kualitatif. Dinas Pariwisata DIY menggunakan media promosi yaitu dengan advertising (periklanan) dengan menggunakan media cetak, media elektronik dan media modern yaitu media sosial. Hasil analisis untuk mengatasi kendala promosi meliputi kerjasama dengan travel agent, memaksimalkan promosi di media sosial, melakukan kerjasama dengan instansi terkait, mengkomunikasikan kepada pemerintah kabupaten/kota untuk mengirimkan peserta yang berbeda dalam pelatihan, mengadakan koordinasi dan menjalin hubungan yang harmonis dengan Dinas Pariwisata kabupaten/kota untuk menentukan prioritas pengembangan pariwisata, memberikan edukasi kepada masyarakat tentang kepariwisataan.
\end{abstract}

Kata Kunci : Dinas Pariwisata DIY, Media Promosi, Wisatawan

\section{ABSTRACT}

DIY Tourism Office is a regional implementing element in tourism sector. DIY Tourism Office has duties to perform tourism affairs, deconcentration authority and co-administration tasks provided by government. Concerning to tourism activities, DIY Tourism Office strives to convey information or promote various kinds of tourism activities in DIY aiming to increase tourist visits to DIY. DIY Tourism Office has some constraints in promoting such as budget constraints, nonoptimal infrastructure, lack of Human Resources quality, lack of synergy or similarity of interests orientation with Tourism Office in the district/city, and lack of public awareness in tourism. Data collection methods used in the Final Project are observation, interview, documentation, participatory, and literature study with qualitative descriptive analysis method. DIY Tourism Office uses promotional media such as print media advertising, electronic media and social media. The analysis results to overcome promotional constraints include collaborating with travel agents, maximizing promotions on social media, collaborating with relevant agencies, communicating to district/city governments to send different participants in training, coordinating and establishing harmonious relations with 
Dinda Puspa Prastiyanti dan Yulianto : MEDIA PROMOSI PADA DINAS PARIWISATA

DAERAH ISTIMEWA YOGYAKARTA DALAM MENINGKATKAN KUNJUNGAN WISATAWAN

District/City Tourism Office to determine tourism development priorities, provide education to the public about tourism.

Keywords: DIY Tourism Office , Promotional Media, Tourist

\section{PENDAHULUAN}

Sektor pariwisata saat ini telah menjadi aspek penting dalam kemajuan ekonomi suatu negara. Pariwisata menjadi pilihan utama dalam pengembangan wilayah. Perkembangan pariwisata telah mengalami banyak perubahan baik perubahan pola, bentuk dan sifat kegiatan perjalanan destinasi wisata. Pembangunan suatu daerah dapat membuka daya tarik wisata baru bagi para wisatawan, baik wisatawan lokal maupun wisatawan mancanegara.

Selain kepariwisataan untuk tempat hiburan, kepariwisataan mempunyai peranan penting untuk memperluas dan memeratakan kesempatan berusaha dan lapangan kerja, mendorong pembangunan daerah, memperbesar pendapatan nasional dalam rangka meningkatkan kesejahteraan dan kemakmuran rakyat serta memupuk rasa cinta tanah air, memperkaya kebudayaan nasional dan memantapkan pembinaannya dalam rangka memperkukuh jati diri bangsa dan mempererat persahabatan antar bangsa.
Dinas

daerah di bidang kepariwisataan. Dinas

Pariwisata Derah Istimewa Yogyakarta memiliki tugas untuk melaksanakan urusan bidang pariwisata, kewenangan dekonsentrasi serta tugas pembantuan yang diberikan oleh pemerintah. (http://visitingjogja.web.id/profile).

Sehubungan dengan kegiatan kepariwisataan Dinas Pariwisata Daerah Istimewa Yogyakarta berusaha untuk dapat selalu menyampaikan informasi atau mempromosikan berbagai macam kegiatan pariwisasta di Daerah Istimewa Yogyakarta dengan tujuan untuk meningkatkan kunjungan wisatawan ke Daerah Istimewa Yogyakarta.

Berdasarkan data yang diperoleh dari Dinas Pariwisata Daerah Istimewa Yogyakarta tahun 2017 mengenai data kunjungan wisatawan dari tahun ke tahun mengalami peningkatan. Peningkatan jumlah kunjungan wisatawan di Daerah Istimewa Yogyakarta dapat dilihat pada tabel di bawah ini.

Tabel 1. Wisatawan DIY Tahun 2013-2017

\begin{tabular}{|c|c|c|c|}
\hline Tahun & Wisnus & Wisman & Jumlah \\
\hline 2013 & 2.602 .074 & 235.893 & 2.837 .967 \\
\hline 2014 & 3.091 .967 & 254.213 & 3.346 .180 \\
\hline 2015 & 3.813 .720 & 308.485 & 4.122 .205 \\
\hline 2016 & 4.194 .261 & 355.313 & 4.549 .574 \\
\hline 2017 & 4.831 .347 & 397.951 & 5.229 .298 \\
\hline
\end{tabular}

Perkembangan kunjungan wisatawan di Daerah Istimewa Yogyakarta dari tahun ke tahun tentunya disebabkan oleh banyak faktor antara lain dari faktor pengelola, faktor pendanaan dan salah satunya adalah faktor promosi. Promosi merupakan komunikasi yang dilakukan oleh perusahaan kepada konsumen yang mempunyai tujuan antara lain untuk memberitahukan, membujuk konsumen untuk membeli, mempengaruhi konsumen untuk menyukai produk, dan menanamkan merek dibenak konsumen. 
Faktor promosi adalah salah satu faktor yang sangat penting dalam memperkenalkan pariwisata di Daerah Istimewa Yogyakarta. Dinas Pariwisata DIY dalam memaksimalkan promosi pariwisata di Yogyakarta menggunakan berbagai media promosi antara lain seperti iklan, videotron, televisi, eventevent, pameran. Namun permasalahan yang dihadapi adanya keterbatasan dana, terutama promosi ke negara-negara Asia, infrastruktur yang belum maksimal misalnya infrastruktur yang berhubungan dengan transportasi dan jalan menuju daerah wisata, kurangnya kualitas Sumber Daya Manusia (SDM) pengelola daya tarik wisata, pendukung dan penunjang kepariwisataan.

\section{LANDASAN TEORI \\ Promosi}

Promosi merupakan komunikasi yang dilakukan oleh perusahaan dengan konsumen. Promosi dilakukan oleh suatu perusahaan dengan tujuan untuk memberitahukan, membujuk konsumen untuk membeli, mempengaruhi konsumen untuk menyukai produk dan menanamkan merek di hati konsumen, dan sebagainya.

Menurut (Ri'aeni, 2015:190), "promosi merupakan kegiatan untuk mengarahkan seseorang atau organisasi kepada tindakan yang menciptakan pertukaran dan pemasaran". Evans dalam (Amaliah dkk., 2015:134) menjelaskan bahwa "promosi adalah segala bentuk komunikasi yang digunakan untuk menginformasikan (to inform), membujuk (to persuade), atau mengingatkan (to remind), orang-orang tentang produk yang dihasilkan organisasi, individu, ataupun rumah tangga".

Daniel dalam (Amaliah dkk., 2015:135), memberikan pendapat bahwa "promosi adalah komunikasi dari para penjual yang menginformasikan, membujuk dan mengingatkan para calon pembeli suatu produk dalam rangka mempengaruhi pendapat mereka atau memperoleh respon". Middleton dalam (Utama, 2017:32) mengemukakan bahwa, "promosi adalah istilah deskriptif singkat dari kegiatan komunikasi, baik secara pribadi maupun melalui media massa yang dilakukan untuk mempengaruhi orang-orang agar membeli suatu produk".

Kotler dan Keller dalam (Aristo, 2016:442) berpendapat bahwa "promosi adalah berbagai cara untuk menginformasikan, membujuk, dan mengingatkan konsumen secara langsung maupun tidak langsung tentang suatu produk atau brand yang dijual".

Berdasarkan uraian yang telah dipaparkan dapat disimpulkan bahwa promosi adalah salah satu teknik komunikasi yang dilakukan oleh suatu organisasi untuk menginformasikan produk yang dihasilkan baik barang maupun jasa dengan tujuan membujuk, mempengaruhi konsumen untuk melakukan pembelian.

\section{Media Promosi}

Media merupakan sarana atau alat yang digunakan untuk menyampaikan pesan dari komunikator kepada komunikan. Media sangat berperan penting dalam membantu mempromosikan hasil produksi baik yang berupa barang maupun jasa.

Ardhi dalam (Amaliah dkk., 2015:135) menjelaskan bahwa media promosi merupakan alat atau sarana yang digunakan untuk promosi. Media promosi dapat dikategorikan ke dalam media cetak konvensional, iklan media cetak, media luar ruang, media online dan media elektronik.

Promosi akan lebih efektif melalui bauran promosi, yaitu kombinasi yang optimal dari pemilihan berbagai jenis kegiatan promosi yang paling efektif dalam meningkatkan penjualan. Middleton dalam (Utama, 2017:32) menyampaikan bahwa "promosi pada umumnya dilakukan dengan media atau cara periklanan, promosi penjualan, hubungan masyarakat, yang dirancang untuk mencapai tujuan yang telah ditentukan”.

Menurut Kotler dalam (Nurhidayati dkk., 2018:90), "Promotion Mix mencakup Periklanan (Advertising), Penjualan Tatap Muka (Personal Selling), Promosi Penjualan (Sales promotion), Publisitas (Publisity), 


\section{WISATAWAN}

Pemasaran Langsung (Direct marketing), dan Pemasaran Melalui Internet (Internet Marketing)".

Berdasarkan uraian yang telah dipaparkan dapat disimpulkan bahwa bauran promosi merupakan kegiatan yang terdiri dari Periklanan (Advertising), Penjualan Tatap Muka (Personal Selling), Promosi Penjualan (Sales promotion), Publisitas (Publisity), Pemasaran Langsung (Direct marketing), dan Pemasaran Melalui Internet (Internet Marketing). Sedangkan media promosi dapat dibedakan menjadi media promosi secara lisan (bertatap muka langsung, melalui telepon, videocall), media tertulis (brosur, leaflet, flyer, poster, billboard, koran), dan elektronik (televisi, radio, internet/sosial media) yang semua itu dapat masuk ke dalam bauran promosi.

\section{Pariwisata}

Industri pariwisata terus mengalami perkembangan baik dari segi teknologi, transportasi, dan informasi yang ditandai dengan terus bertambahnya jumlah destinasi wisata yang ada di Indonesia maupun negara lainnya. Dadang Rizki Ratman dalam (Ghani, 2017:23) memaparkan bahwa "meningkatnya jumlah destinasi dan investasi di sektor pariwisata telah menjadi salah satu sektor ekonomi yang paling pesat pertumbuhannya di dunia. Sektor pariwisata merupakan kunci dalam pendapatan ekspor, penciptaan lapangan kerja dan pengembangan usaha dan infrastruktur".

Hunziker dan Krapf dalam (Lemy, 2018:4) menjelaskan bahwa, "pariwisata adalah jumlah dari fenomena dan hubungan yang terjadi dari perjalanan dan tinggal sebagai bukan penduduk, dan sejauh mereka tidak bertujuan untuk menjadi penduduk tetap dan tidak berhubungan dengan kegiatan mencari uang".

Menurut Yoeti dalam (Ri'aeni', 2015:190) memaparkan bahwa, "Pariwisata (tourism) adalah suatu perjalanan yang dilakukan untuk sementara waktu, yang diselenggarakan dari suatu tempat ke tempat lain, dengan maksud bukan untuk berusaha (business) atau mencari nafkah di tempat yang dikunjungi, tetapi semata-mata untuk menikmati perjalanan tersebut, untuk bertamasya dan rekreasi atau memenuhi keinginan yang beranekaragam."

Dari uraian yang telah dipaparkan dapat disimpulkan bahwa pariwisata merupakan suatu kegiatan perjalanan yang dilakukan untuk sementara waktu dari suatu tempat ke tempat lain dan tinggal sebagai bukan penduduk yang bertujuan untuk liburan, bisnis, dan tujuan lainnya selama tidak lebih dari satu tahun.

\section{Wisatawan}

Industri pariwisata merupakan kumpulan usaha pariwisata yang saling terkait dalam menghasilkan barang atau jasa bagi pemenuhan kebutuhan wisatawan dalam penyelenggaraan pariwisata. Menurut Undang-Undang No. 10 Tahun 2009, "Wisatawan adalah orang yang melakukan wisata". Soekadijo dalam (Purwanti dan Retno, 2014:3) memaparkan bahwa "wisatawan adalah orang yang mengadakan perjalanan dari tempat kediamannya tanpa menetap di tempat yang didatanginya, atau hanya untuk sementara waktu tinggal ditempat yang didatanginya".

(Suwena dan Gusti, 2017:30) berpendapat bahwa "wisatawan (tourist) yaitu orang yang melakukan perjalanan wisata". Sedangkan Internasional Union of Official Travel Organization (IUOTO) dalam (Suwena dan Widyatmaja, 2017:34) menjelaskan bahwa, "wisatawan (tourist) adalah setiap orang yang bertempat tinggal di suatu negara tanpa memandang kewarganegaraannya, berkunjung ke suatu tempat pada negara yang sama untuk jangka waktu lebih dari 24 jam".

Berdasarkan uraian yang telah dipaparkan dapat disimpulkan bahwa wisatawan adalah orang yang melakukan wisata yang mengadakan perjalanan hanya untuk sementara waktu dan bertempat tinggal di suatu negara tanpa memandang kewarganegaraannya. 


\section{Jenis-Jenis Wisatawan}

Berdasarkan sifat perjalanan, lokasi dimana perjalanan dilakukan, Gitapati dalam (Riswanto dan Rian, 2018:151) mengklasifikasikan wisatawan sebagai berikut:

1. Foreign Tourism, istilah ini sering disebut dengan wisatawan mancanegara.

2. Domestic Foreign Tourist, orang atau wisatawan asing yang berada/berdiam atau bertempat tinggal di suatu negara yang melakukan perjalanan wisata di wilayah negara di tempat dia tinggal.;

3. Domestic Tourist, adalah Wisatawan Dalam Negeri (WDN);

4. Indigenous Foreign Tourist adalah warga suatu negara tertentu yang bertugas di negara lain dan pulang ke negara asalnya untuk melakukan perjalanan wisata di negaranya sendiri.;

5. Transit Tourist adalah wisatawan yang sedang melakukan perjalanan wisata ke suatu negara tertentu dengan menggunakan kapal udara atau kapal laut ataupun kereta api yang terpaksa singgah pada suatu pelabuhan/ airport/ stasiun bukan atas kehendaknya sendiri.

\section{METODE}

Menurut Arikunto dalam (Siyoto dan Ali, 2015:82) menjelaskan bahwa, "desain penelitian merupakan jalan bagi peneliti untuk menentukan arah berlangsungnya proses penelitian secara benar dan tepat agar mencapai tujuan yang telah ditetapkan". Penelitian yang digunakan oleh peneliti yaitu penelitian deskriptif kualitatif dimana metode penelitian tersebut dilakukan secara intensif, peneliti ikut berpartisipasi langsung di lapangan dan mencatat apa saja yang terjadi di lapangan, kemudian menganalisis dan mengevaluasi dengan berbagai dokumen yang ditemukan di lapangan, dan membuat laporan (Sugiyono, 2018:16). Peneliti menggunakan metode penelitian ini guna mengetahui dan memberikan informasi mengenai Media Promosi pada Dinas Pariwisata Daerah Istimewa Yogyakarta dalam meningkatkan kunjungan wisatawan serta kendala yang dihadapi Dinas Pariwisata Daerah Istimewa Yogyakarta dalam melakukan promosi. Sedangkan teknik pengambilan data melalui observasi, interview, parisipatif, dokumentasi dan studi pustaka.

\section{HASIL DAN PEMBAHASAN \\ Dinas Pariwisata DIY}

Dinas Pariwisata Daerah Istimewa Yogyakarta (DIY) adalah lembaga pemerintahan yang bergerak di bidang pariwisata tingkat provinsi. Dinas Pariwisata Daerah Istimewa Yogyakarta ditetapkan berdasarkan Peraturan Daerah Provinsi DIY Nomor: 6 Tahun 2008 tentang Pembentukan dan Organisasi Dinas Daerah di lingkungan Pemerintah Provinsi Daerah Istimewa Yogyakarta. Berdirinya dinas ini bertujuan untuk meningkatkan pembangunan kepariwisataan sebagai salah satu upaya untuk meratakan pendapatan dan pembangunan dalam rangka pengisian otonomi yang nyata, dinamis dan bertanggung jawab yang dapat menjamin perkembangan dan pembangunan daerah. (http://visitingjogja.com/)

Berdasarkan Peraturan Daerah, Daerah Istimewa Yogyakarta Nomor 3 Tahun 2015 Tentang Kelembagaan Pemerintah Daerah, Daerah Istimewa Yogyakarta, Dinas Pariwisata memiliki tugas untuk melaksanakan urusan bidang pariwisata, kewenangan dekonsentrasi serta tugas pembantuan yang diberikan oleh pemerintah. Untuk melaksanakan tugasnya, maka Dinas Pariwisata mempunyai fungsi yaitu (1) penyusunan program kerja,(2) perumusan kebijakan teknis bidang pariwisata,(3) pengelolaan pengembangan kapasitas pariwisata,(4) penyelenggaraan pemasaran pariwisata,(5) pemberian fasilitasi bidang pariwisata Kabupaten atau Kota,(6) pelaksanaan pelayanan umum bidang pariwisata,(7) pemanfaatan budaya untuk promosi pariwisata,(8) pemberdayaan sumber daya dan mitra kerja bidang pariwisata,(9) pelaksanaan kegiatan ketatausahaan,(10) pelaksanaan tugas lain 
yang diberikan oleh Gubernur sesuai dengan tugas dan fungsinya. (http://visitingjogja.com/).

\section{Media Promosi untuk meningkatkan Kunjungan wisatawan}

Daerah Istimewa Yogyakarta merupakan salah satu kota tujuan wisata di Indonesia yang banyak dikunjungi wisatawan baik wisatawan nusantara maupun wisatawan mancanegara. Berbagai macam daya tarik wisata (DTW) terdapat di Daerah Istimewa Yogyakarta antara lain wisata alam, wisata budaya, dan wisata buatan. Beberapa diantaranya merupakan daya tarik wisata (DTW) yang sudah sangat terkenal secara nasional diantaranya seperti Malioboro, Kraton, Candi Prambanan, dan Pantai Parangtritis. Untuk meningkatkan kunjungan wisatawan baik wisatawan nusantara maupun wisatawan mancanegara maka perlu adanya promosi terhadap destinasi-destinasi wisata yang ada di Daerah Istimewa Yogyakarta. Media promosi yang dilakukan sebagai berikut:

\section{Periklanan (Advertising).}

Dinas Pariwisata Daerah Istimewa Yogyakarta (DIY) melakukan promosi dengan cara periklanan (advertising) menggunakan media konvensional baik media cetak maupun media elektronik dan menggunakan media modern.

a. Media cetak

1) Brosur merupakan suatu alat untuk promosi barang, jasa dan lain-lain. Brosur ini digunakan untuk memberikan informasi dan menarik perhatian kepada masyarakat mengenai kegiatan-kegiatan atau event-event yang akan diselenggarakan oleh Dinas Pariwisata DIY dan disebarkan kepada masyarakat atau wisatawan dengan cara dibagikan ketika sedang ada event-event.

2) Calender of Event (Agenda Wisata) merupakan jadwal kegiatan-kegiatan yang berhubungan dengan event- event wisata yang menunjukkan hari, tanggal, waktu, dan tempat kegiatan. Hal ini digunakan untuk menginformasikan kepada masyarakat atau wisatawan mengenai jadwal event atau kegiatan yang akan diadakan oleh Dinas Pariwisata DIY maupun Dinas Pariwisata Kabupaten/Kota dan bisa didapatkan di kantor Tourist Information Center (TIC) Malioboro,

3) Guide Book (Buku Panduan Wisata) merupakan buku petunjuk yang memuat berbagai macam keterangan mengenai objek wisata, sarana wisata, dan sebagainya. Guide book ini digunakan untuk memberikan penjelasan kepada masyarakat mengenai sejarah-sejarah destinasi wisata di Daerah Istimewa Yogyakarta dan bisa didapatkan di kantor Tourist Information Center (TIC).

4) Peta Wisata merupakan peta yang menggambarkan atau menjelaskan lokasi tempat tujuan wisata di dalam suatu kota atau kabupaten, yang sudah menggabungkan informasi pariwisata.

5) Baliho/Billboard

Baliho merupakan media promosi yang digunakan untuk memberitakan informasi kegiatan yang berhubungan dengan masyarakat yang berukuran besar. Baliho ini digunakan untuk menginformasikan dan menarik wisatawan mengenai event atau kegiatan yang akan diadakan oleh Dinas Pariwisata DIY

6) Spanduk merupakan kain membentang dan biasanya berada di tepi-tepi jalan yang berisi tulisan, warna dan gambar.

b. Media Elektronik

1) Televisi merupakan sebuah media massa elektornik terkenal yang berfungsi sebagai penerima siaran gambar bergerak beserta suara yang 
berfungsi memberikan informasi serta hiburan kepada publik.

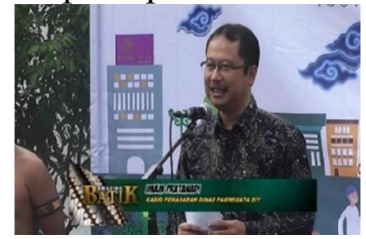

\section{Gambar 1. Iklan Televisi Dinas Pariwisata DIY}

2) Videotron merupakan media iklan yang berupa video, animasi, dan teks berjalan.Videotron ini digunakan untuk memberikan informasi kepada masyarakat ataupun wisatawan mengenai potensi pariwisata di Daerah Istimewa Yogyakarta, mengenai kegiatan yang akan diselenggarakan oleh Dinas Pariwisata DIY maupun Dinas Pariwisata Kabupaten/Kota.

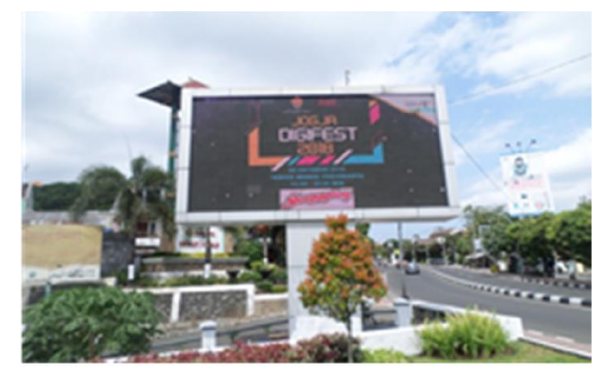

\section{Gambar 2. Videotron Dinas Pariwisata DIY}

3) Film-film merupakan alat audio visual dengan tampilan yang diproduksi secara khusus untuk pertunjukan di gedung atau di bioskop, di dalam film juga memuat adegan yang terasa hidup karena adanya kombinasi antara suara, tata warna, kostum, panorama yang indah, dan memiliki daya pikat yang dapat memberi kepuasan kepada penonton.

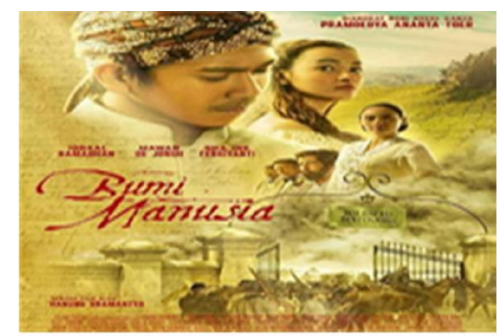

Gambar 3. Film Bumi Manusia

c. Media Modern

1) Website yang digunakan adalah https://visitingjogja.com. Website dapat memuat berita terkini berbagai informasi mengenai destinasi obyek wisata, akomodasi, agenda/event, kuliner.

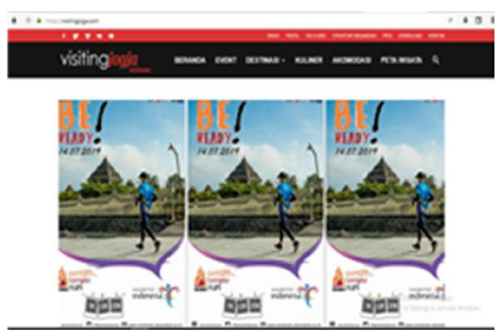

\section{Gambar 4. Website Dinas Pariwisata DIY}

2) Instagram, Instagram Dinas Pariwisata DIY menggunakan nama seperti website yaitu visitingjogja.com. Instagram ini dikelola oleh bidang Program dan Informasi, serta melalui instagram bisa didapatkan informasi mengenai spot-spot wisata baik yang sudah lama ataupun yang baru, foto-foto tempat wisata yang sedang populer, serta info event-event terbaru

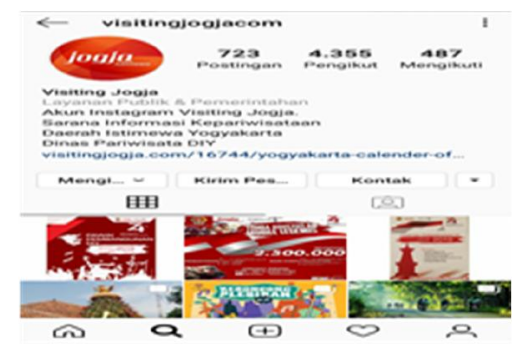

Gambar 5. Instagram Dinas Pariwisata DIY 
3) Twitter, akun twitter yang digunakan oleh Dinas Pariwisata DIY yaitu visiting_jogja, berisi mengenai destinasi-destinasi wisata yang berada di Yogyakarta serta informasi mengenai event-event.

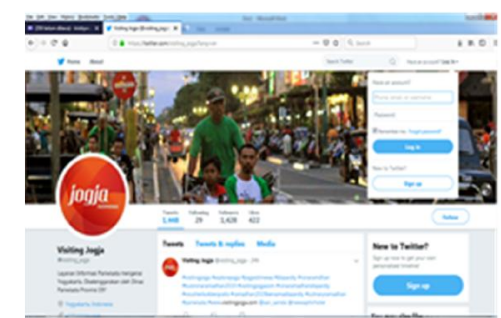

\section{Gambar 6. Twitter Dinas Pariwisata DIY}

4) Facebook, akun facebook sama dengan akun yang lain yaitu visiting jogja. Facebook ini dikelola oleh bidang Program dan Informasi, serta dari facebook banyak didapatkan informasi-informasi mengenai eventevent yang akan diselenggarakan, foto-foto tempat wisata dan kegiatankegiatan serta informasi-informasi yang lainnya.

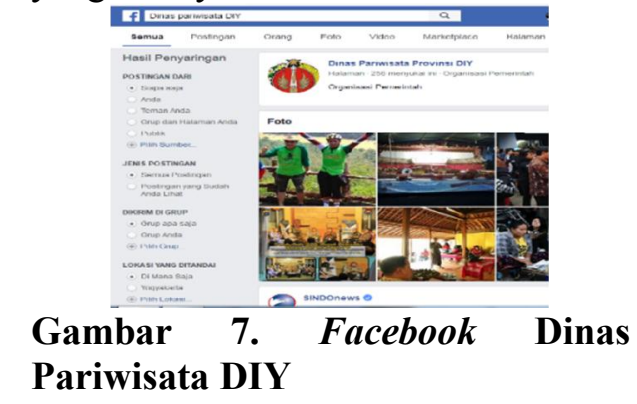

5) Youtube, melalui youtube dapat membuat iklan yang lebih leluasa lagi. Wisatawan asing dapat lebih mengenal pariwisata di Yogyakarta melalui youtube ini, karena youtube ini dalam bahasa Inggris memiliki subtitle dengan bahasa Indonesia.

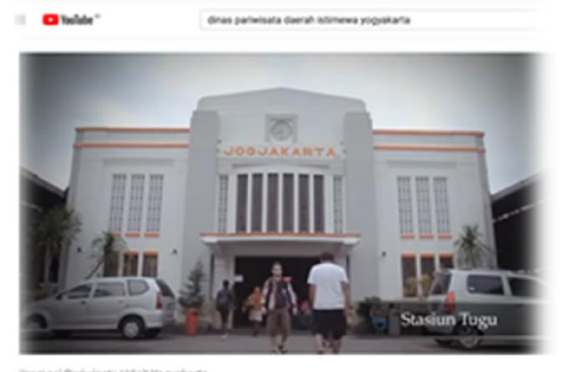

Gambar 8. Youtube Dinas Pariwisata DIY

\section{b. Public Relations}

Untuk meningkatkan jumlah wisatawan ke Yogyakarta, salah satu media yang digunakan adalah dengan Public relations (hubungan masyarakat). Public Relations (hubungan masyarakat) merupakan kegiatan penciptaan pemahaman melalui pengetahuan dan kegiatan-kegiatan agar muncul dampak perubahan yang positif. Bentuk Public Relations yang dilakukan dengan mengadakan atau menyelenggarakn eventevent baik di dalam negeri maupun luar negeri.

1. Mengadakan Event

Beberapa event-event yang diselenggaran antara lain Jogja Travel Mart, Jogja Air Show, Road to Jogja Fashion Week, Tour de Jogja, Malioboro Night Festival, Pawai Pembangunan, Pameran Pembangunan, Jogja International Street Performance, Jogja International Heritage Walk, Jogja Digifest, Pameran Pasar Malam Perayaan Sekaten.

2. Bekerjasama dengan Konsulat Jendral Republik Indonesia (KJRI) dan Visit Indonesian Tourism Officer (VITO).

Untuk memperkenalkan pariwisata Yogyakarta di mancanegara, Dinas Pariwisata menyelenggarakan beberapa pameran yakni antara lain NATAS Travel Fair di Singapore Expo, Singapura, MATTA Fair di PWTC, Kuala Lumpur, Malaysia, JATA Tourism Expo di Tokyo 
Big Sight, Tokyo, Jepang, dan Thai International Travel di Kunming, Cina.

Berdasarkan uraian yang telah dipaparkan dapat disimpulkan bahwa media promosi yang digunakan Dinas Pariwisata DIY berdasarkan pendapat dari Middleton dalam (Utama, 2017:32) bahwa "promosi pada umumnya dilakukan dengan media atau cara periklanan, promosi penjualan, hubungan masyarakat, yang dirancang untuk mencapai tujuan yang telah ditentukan". Advertising (periklanan) memiliki tujuan untuk memberikan atau menyampaikan informasi selengkap-lengkapnya kepada wisatawan, serta membujuk para wisatawan agar mau menghadiri kegiatan-kegiatan pariwisata dan mau mengunjungi tempat-tempat wisata. Hal ini berdasarkan pendapat dari Basu Swastha dalam (Tasruddin, 2015:109-110). Dinas Pariwisata DIY selain menggunakan media promosi advertising (periklanan) juga menggunakan media promosi berupa public relations (hubungan masyarakat) yang memiliki tujuan memperkenalkan destinasi wisata Daerah Istimewa Yogyakarta kepada para wisatawan yang datang ke Daerah Istimewa Yogyakarta serta dapat untuk mendidik para wisatawan atau anak muda mengenai seni budaya. Hal ini sesuai dengan pendapat dari Morissan (2015:39).

Dalam pelaksanaan promosi mengalami kendala yakni :

1. Anggaran merupakan faktor penting dalam kegiatan event namun dalam mengajukan usulan tidak semua disetujui oleh Tim Anggaran Pemerintah Daerah (TAPD) terutama yang berhubungan dengan kegiatan promosi ke luar negeri.

2. Infrastruktur yang belum optimal, belum tersedianya infrastruktur yang optimal, terutama untuk transportasi baik untuk jalan maupun kendaraan menuju tempat wisata.

3. Kurangnya Kualitas Sumber Daya Manusia (SDM) Pengelola Daya Tarik Wisata, Pendukung dan Penunjang Kepariwisataan.

4. Kurangnya Sinergitas atau Kesamaan Orientasi Kepentingan antara Dinas
Pariwisata DIY dengan pemerintah Kabupaten/Kota atau tidak adanya kolaborasi atau kesamaan antara Dinas Pariwisata DIY dengan Dinas Pariwisata Kabupaten/Kota di seluruh DIY.

5. Kurangnya Kesadaran Masyarakat yang enggan diajak bekerjasama dalam membangun, mengembangkan serta memasarkan destinasi wisata yang ada di daerah tersebut.

Berdasarkan uraian yang telah dipaparkan dapat disimpulkan bahwa Dinas Pariwisata DIY dalam melakukan promosi menghadapi beberapa kendala diantaranya masalah keterbatasan anggaran, infrastruktur, kurangnya kualitas Sumber Daya Manusia dalam mengelola daya tarik wisata, pendukung dan penunjang kepariwisataan, kurangnya sinergitas atau kesamaan orientasi kepentingan antara Dinas Pariwisata DIY dengan Dinas Pariwisata di kabupaten/ kota dan kurangnya kesadaran dari sebagian masyarakat dalam mengembangkan destinasi wisata. Adanya kendala-kendala tersebut diharapkan tidak mengurangi kunjungan wisatawan yang datang ke Daerah Istimewa Yogyakarta.

Upaya mengatasi permasalahan dalam melakukan promosi

Ada beberapa terobosan untuk mengatasi permasalahan yang dihadapinya dalam melakukan promosi.

1. Anggaran yang terbatas, upaya yang dapat dilakukan yaitu dengan cara Dinas Pariwisata DIY bekerjasama dengan travel agent agar memasukkan destinasi wisata baru dalam rencana perjalanan (paket wisata), memaksimalkan promosi di media sosial, dengan perkembangan teknologi smartphone yang semakin canggih maka informasi tentang pariwisata di Yogyakarta dapat dengan mudah dan cepat diakses oleh siapapun, kapanpun dan dimanapun baik wisatawan dalam negeri maupun wisatawan luar negeri.

2. Infrastruktur yang belum maskimal yaitu dengan cara melakukan pendekatanpendekatan dengan instansi-instansi terkait, misalnya dengan Dinas Pekerjaan Umum 


\section{WISATAWAN}

dan Perumahan Rakyat seperti pembangunan infrastruktur akses jalan, tempat ibadah, tempat MCK (Mandi Cuci Kakus), dengan Dinas Lingkungan Hidup dan dengan Dinas Perhubungan dan Transportasi seperti mengupayakan ketersediaan transportasi gratis menuju tempat wisata bagi wisatawan rombongan yang kesulitan untuk mencapai daerah wisata dari area parkir yang jauh dari tempat wisata misalkan dari parkiran bus Ngabean menuju Kraton Yogyakarta.

3. Mengatasi Kurangnya Kualitas Sumber Daya Manusia (SDM) Pengelola Daya Tarik Wisata, Pendukung dan Penunjang Kepariwisataan yaitu dengan cara Dinas Pariwisata DIY mengupayakan dan mengkomunikasikan kepada pemerintah kabupaten/kota untuk mengirimkan peserta yang berbeda dalam pelatihan desa wisata sehingga yang mendapatkan informasi serta pengetahuan tidak hanya satu orang saja tetapi bisa lebih banyak dan merata.

4. Mengatasi Kuranganya Sinergitas atau Kesamaan Orientasi Kepentingan yaitu dengan selalu mengadakan koordinasi dan menjalin hubungan yang harmonis dengan Dinas Pariwisata Kaupaten/Kota untuk membahas prioritas yang diutamakan dalam pengembangan wisata.

Mengatasi Kurangnya Kesadaraan Masyarakat yaitu dengan memberikan pengertian dan edukasi kepada masyarakat secara lebih intens seperti pelatihan sadar wisata kepada masyarakat agar mampu berpikir secara kepariwisataan, agar dapat saling bekerjasama dalam mempromosikan pariwisata DIY.

\section{KESIMPULAN}

Media promosi yang digunakan oleh Dinas Pariwisata DIY meliputi: Advertising (periklanan) yang menggunakan media promosi berupa media cetak, media elektronik, media modern atau media sosial dan media public relations (hubungan masyarakat), yang dilakukan oleh Dinas
Pariwisata DIY dengan mengadakan atau menyelenggarakan event-event atau pameran-pameran baik di dalam negeri maupun luar negeri dan bekerjasama dengan KJRI (Konsulat Jendral Republik Indonesia) dan VITO (Visit Indonesia Tourism Office) yaitu perwakilan promosi wisata mancanegara dari Kementerian Pariwisata.

Keterbatasan yang dihadapi Dinas Pariwisata DIY dalam Melakukan Promosi keterbatasan anggaran, infrastruktur yang kurang optimal, kurangnya kualitas sumber daya manusia pengelola daya tarik wisata. Sehingga diperlukan upaya untuk mengatasi hal tersebut. Upaya yang dilakukan, diantaranya bekerjasama dengan travel agent serta memaksimalkan promosi di media sosial serta infrakstruktur yang lebih dioptimalkan terutama jalan menuju tempat wisata yang masih sempit dan rusak, pembangunan tempat ibadah serta tempat MCK (Mandi Cuci Kakus), dan mengupayakan ketersediaan transportasi gratis menuju tempat wisata bagi wisatawan rombongan yang kesulitan untuk mencapai daerah wisata. Peningkatan sumber daya manusia dengan mengirimkan pelatihan dan sinergiritas koordinasi yang harmonis dengan dinas pariiwsata kabupaten sekitarnya. Memberikan pengertian dan edukasi kepada masyarakat agar dapat saling bekerjasama dalam mempromosikan pariwisata DIY.

\section{DAFTAR PUSTAKA}

Amaliah, Norma, Achmad Yanu Alif Fianto, dan Sigit Prayitno Yosep. ( 2015). Perancangan Media Promosi PT Petronika Sebagai Upaya Pembentukan Citra Perusahaan. Jurnal Desain Komunikasi Visual, IV(1). Diambil dari https://media.neliti.commediapublicatio ns244687-perancangan-media-promosipt-petronika-s-1bac1544.pdf

Aristo, Stephanus Felix. (2016). Pengaruh Produk, Harga, dan Promosi Terhadap Keputusan Pembelian Konsumen Woles Chips. Performa: Jurnal Manajemen dan Start-Up Bisnis, I, 
441-447. Diambil dari https://journal.uc.ac.idindex.phpperfor ma articleview220203

Ghani, Yosef Abdul . (2017). Pengembangan Sarana Prasarana Destinasi Pariwisata Berbasis Budaya di Jawa Barat. Jurnal Pariwisata, XIV(1), 22-31. Diambil dari https://ejournal.bsi.ac.idejurnalindex.ph pjparticleview 4461pdf

Lemy, Diena. (2018). Jasa Pariwisata. Yogyakarta: Explore

Morissan. (2015). Periklanan Komunikasi Pemasaran Terpadu. Jakarta: Prenada Media Group

Nurhidayati, Endang, Sampurno, dan Djoharsyah. (2018). Pengaruh Bauran Promosi Sampo Hijab Terhadap Keputusan Pembelian dan Pengaruhnya Terhadap Kepuasan Konsumen di Kota Bogor. Jurnal Ekonomi, $\quad X X(1)$ Pebruari 2018, 90-105. Diambil dari https:// scholar. google.co. idcitationshl $=$ id\&venue $=$ s3LAjxDqBkwJ.2018\&vq=id\&view_o $\mathrm{p}=$ hcore citedby $\&$ hcore_ pos $=1$

Pariwisata RI. (2009). Undang-Undang Nomor 10 Tahun 2009 tentang Kepariwisataan. Jakarta: Kementerian Pariwisata RI

Purwanti, Novi Dwi, dan Retno Mustika Dewi. ( 2014). Pengaruh Jumlah Kunjungan Wisatawan Terhadap Pendapatan Asli Daerah Kabupaten Mojokerto Tahun 2006-2013. Jurnal Ilmiah Tahun 2014, 1-12. Diambil dari https://jurnalmahasiswa.unesa.ac.idinde x.phpjupearticleview934 29257

Ri'aeni, Ida. (2015). Penggunaan New Media dalam Promosi Pariwisata Daerah Situs Cagar Budaya di Indonesia. Jurnal Komunikasi, IX(2) April 2015, 22-31. Diambil dari https://journal.uii.ac.idjurnalkomunikasiarticle viewFile 71786362

Riswanto, Ari, dan Rian Andriani. (2018). Maksimalisasi Potensi Geowisata dalam Meningkatkan Kunjungan Wisatawan. Jurnal Pariwisata, V(2) September 2018, 147-155. Diambil dari https://ejournal.bsi.ac.idejurnal index.phpjparticleview 4461pdf

Siyoto, Ali Sodik. (2015). Dasar Metodologi Penelitian. Yogyakarta: Literasi Media Publishing

Sugiyono. (2018). Metode Penelitian Kuantitatif. Bandung: Alfabeta

Suwena, I Ketut, dan I Gusti Ngurah Widyatmaja. (2017). Pengetahuan Dasar Ilmu Pariwisata. Denpasar Bali: Pustaka Larasan

Tasruddin, Ramsiah. (2015). Strategi Promosi Periklanan yang Efektif. Jurnal Al-Khitabah, II(1), 107-116. Diambil dari http://journal. uinalauddin.ac.idindexphpAlKhitabaharticl edownload2623247

Utama, I Gusti Bagus Rai. (2017). Pemasaran Pariwisata. Yogyakarta: CV Andi Offse 